\title{
MENINGKATKAN HASIL BELAJAR MATERI IPS MELALUI MODEL PEMBELAJARAN DIRECT INSTRUCTION DENGAN PENDEKATAN SCIENTIFIC
}

\author{
Rahmat Abdullah \\ Guru Mata Pelajaran IPS SMPN 1 Tanete Rilau Kabupaten Barru \\ Email: rahmatabdullah971@gmail.com
}

\begin{abstract}
This study aims: (1) To improve the learning outcomes of social studies material through direct instruction learning models with a scientific approach, class $\mathrm{VII}_{4}$ students of SMPN 1 Tanete Rilau, Barru Regency. (2) To find out the percentage of completeness in learning social studies material, class $\mathrm{VII}_{4}$ students of SMPN 1 Tanete Rilau, Barru district. (3) To determine changes in the teacher's ability to manage and control direct instruction learning models with the scientific approach. (4) To find out the change in activity students carry out direct instruction learning models with the scientific approach. This research was conducted in three cycles. Each cycle consists of four stages of activities which include: (a) Stage of planning (planning), (b) stages of implementation of actions (acting), (c) stages of observation (observing) and (d) reflection stage (reflecting). The subjects of this study were 31 female respondents of all types. Qualitative data on student activity and teacher ability, while quantitative data on learning outcomes per cycle. The results of the study show that: (1) the learning outcomes of the IPS material, the difference in average increases by 12.26 , increases in the category of less than good from cycle two to cycle three. (2) The percentage of completeness in studying social studies material reached $90.32 \%$ in the third cycle. (3) Changes in the ability of teachers, increasing the score of the percentage difference of $20 \%$, increasing the category enough to be good. (4) Changes in the activity of students increased by a score of $10 \%$ difference in percentage, an increase in the category to be good enough.
\end{abstract}

Keywords: The results of learning IPS material, direct instruction, scientific.

Abstrak. Penelitian ini bertujuan: (1) Untuk meningkatkan hasil belajar materi IPS melalui model pembelajaran direct instruction dengan pendekatan scientific, siswa kelas $\mathrm{VII}_{4}$ SMPN 1 Tanete Rilau Kabupaten Barru. (2) Untuk mengetahui persentase ketuntasan belajar materi IPS, siswa kelas VII 4 SMPN 1 Tanete Rilau kabupaten Barru. (3) Untuk mengetahui perubahan kemampuan guru dalam mengelolah dan mengendalikan model pembelajaran direct instruction dengan pendekatan scientific. (4) Untuk mengetahui perubahan aktivitas peserta didik melaksanakan model pembelajaran direct instruction dengan pendekatan scientific. Penelitian ini dilaksanakan tiga siklus. Setiap siklus terdiri dari empat tahap kegiatan yang meliputi: (a) Tahap perencanaan (planning), (b) tahap implementasi tindakan (acting), (c) tahap observasi (observing) dan (d) tahap refleksi (reflecting). Subyek penelitian ini 31 orang responden berjenis perempuan semua. Data kualitatif aktivitas peserta didik dan kemampuan guru, sedang data kuantitatif hasil belajar tiap siklus. Hasil penelitian menunjukkan bahwa: (1) Hasil belajar materi IPS, meningkat rerata selisih 12,26, meningkat kategori kurang menjadi baik dari siklus dua ke siklus tiga. (2) Persentase ketuntasan belajar materi IPS, mencapai 90,32\% siklus tiga. (3) Perubahan kemampuan guru, meningkat skor persentase selisih 20\%, meningkat kategori cukup menjadi baik. (4) Perubahan aktivitas peserta didik meningkat skor persentase selisih 10\%, meningkat kategori cukup menjadi baik.

Kata Kunci: Hasil belajar materi IPS, direct instruction, scientific. 


\section{PENDAHULUAN}

Menurut dokumentasi guru sebagai hasil pengamatan kondisi peserta didik kelas $\mathrm{VII}_{4}$ SMPN 1 Tanete Rilau kabupaten Barru semester satu tahun pelajaran 2016-2017, pada saat pelaksanaan pembelajaran IPS, yaitu keberhasilan pelajaran materi IPS masih menjadi kendala, setelah melakukan kegiatan pembelajaran dengan langkah-langkah ilmiah. Demikian juga, selama proses belajar mengajar masih terlihat beberapa anak yang kurang antusias, masih rendahnya partisipasi siswa selama proses pembelajaran, juga kurangnya pemahaman terhadap materi yang telah diberikan. Hal ini dilihat dari sikap siswa yang cenderung malu untuk mengungkapkan pendapatnya, jika diadakan tanya jawab. Mereka memilih diam tidak bertanya meskipun sebenarnya mereka belum paham tentang materi yang sedang dibahas. Sebagian siswa juga masih malu untuk maju ke depan jika diminta guru secara suka rela untuk menjelaskan kembali apa yang mereka terima setelah mendengarkan penjelasan. guru. Dibutuhkan waktu yang cukup lama untuk membujuk siswa agar mau mempresentasikan hasil pekerjaannya.

Berdasarkan survey awal yang dilakukan peneliti, sebagai hasil koreksi ujian semester satu tahun pelajaran 2016-2017, siswa kelas $\mathrm{VII}_{4}$ SMPN 1 Tanete Rilau kabupaten Barru, sebelum diberikan perbaikan bahwa: Hanya 70,35\% peserta didik yang tuntas belajarnya dari sebanyak 30 orang, tidak mencapai standar ketuntasan belajar minimal secara kalsikal minimal 85\%. (Rahmat, 2016).

Pustaka yang digunakan dalam penelitian ini sebagai berikut:

Hasil belajar materi pelajaran IPS adalah hasil yang diperoleh siswa setelah melakukan suatu kegiatan belajar materi pelajaran IPS dalam waktu tertentu. Misalnya hasil belajar yang diperoleh setelah melakukan kegiatan belajar setiap siklus. Hasil belajar dapat dilihat setelah diberikan tindakan dan kemudian diberikan tes.

Model pembelajaran direct instruktion dengan penekatan scientific adalah penerapan lima sintak pembelajaran langsung dengan menyesuaikan pelaksanaan keenam tahap strategi scientific.

Model pembelajaran Direct Instruction dapat dilaksanakan pada kegiatan pembelajaran yang bersaitifik dengan berdasarkan pada sintak model pembelajaran tersebut. Sehingga penerapannya dalam proses pembelajaran disinergikan dengan langkah/kegiatan saintifik $5 \mathrm{M}$, menurut tabel 1 berikut:

Tabel 1. Sintaks model pembelajaran direct instruction dengan Pendekatan scientific

\begin{tabular}{|c|l|l|}
\hline $\begin{array}{c}\text { Fase } \\
\text { ke- }\end{array}$ & \multicolumn{1}{|c|}{ Nama fase } & \multicolumn{1}{c|}{ Kegiatan guru } \\
\hline 1 & $\begin{array}{l}\text { Establishing set } \\
\text { Menyampaikan tujuan dan } \\
\text { mempersiapkan peserta didik }\end{array}$ & $\begin{array}{l}\text { Menjelaskan tujuan pembelajaran, informasi latar belakang } \\
\text { pelajaran, dan mempersiapkan peserta didik untuk belajar. }\end{array}$ \\
\hline 2 & $\begin{array}{l}\text { Demonstrating } \\
\text { Mendemonstrasikan } \\
\text { keterampilan }\end{array}$ & $\begin{array}{l}\text { Mendemonstrasikan pengetahuan atau keterampilan yang benar } \\
\text { dan menyajikan informasi tahap demi tahap (ada unsur scientifik; } \\
\text { pengamatan). }\end{array}$ \\
\hline 3 & $\begin{array}{l}\text { Guided practice } \\
\text { Membimbing pelatihan }\end{array}$ & $\begin{array}{l}\text { Merencanakan dan memberikan pelatihan awal, (ada unsur } \\
\text { scientifik; mengumpulkan informasi). }\end{array}$ \\
\hline 5 & $\begin{array}{l}\text { Feed back } \\
\text { mengecek pemahaman dan }\end{array}$ & $\begin{array}{l}\text { Mengecek apakah peserta didik telah berhasil melakukan } \\
\text { tugasnya dengan baik dan memberikan umpan balik. (unsur } \\
\text { scientific; mengasosiasi). }\end{array}$ \\
\hline $\begin{array}{l}\text { Memberikan umpan balik } \\
\text { pentuk pelatihan lanjutan dan }\end{array}$ & $\begin{array}{l}\text { Mempersiapkan dan memberikan kesempatan kepada siswa untuk } \\
\text { melakukan pelatihan lanjutan, dengan perhatikan khusus kepada } \\
\text { situasi yang lebih kompleks dalam kehidupan sehari-hari. (unsur } \\
\text { scientific; mengkomunikasikan). }\end{array}$ \\
\hline
\end{tabular}




\section{METODE PENELITIAN}

Penelitian ini adalah penelitian tindakan kelas (classroom action research), berupa tindakan (action) yang diwujudkan dalam bentuk siklus-siklus yang diterapkan. Setiap siklus terdiri empat tahap pengembangan yaitu plan (perencanan), action (tindakan), observing (observasi), reflecting (refleksi).

Direct instruction dengan pendekatan scientific dilaksanakan tiga kali siklus. Setiap siklus dilaksanakan berupa tindakan (action) yang diwujudkan dalam bentuk siklus-siklus yang diterapkan. Setiap siklus meliputi empat tahap pengembangan yaitu plan (perencanan), action (tindakan), observing (observasi), reflecting (refleksi). Untuk mengukur hasil belajar materi IPS melalui model pembelajaran direct instruction dengan pendekatan scientific siswa kelas $\mathrm{VII}_{4}$ SMPN 1 Tanete Rilau kabupaten Barru, diberikan tes prestasi bentuk essai pada setiap akhir siklus. Kemudian hasil tes dilakukan perhitungan untuk mendapatkan data hasil belajar materi IPS. Data hasil belajar

Tabel 2. Hasil penelitian kemampuan guru dalam mengelolah dan mengendalikan model direct instruction tiap siklus

\begin{tabular}{cccc}
\hline \multirow{2}{*}{ Uraian } & \multicolumn{3}{c}{ Perkembangan kemampuan guru tiap siklus } \\
& Siklus 1 & Siklus 2 & Siklus 3 \\
\hline JML & 11,5 & 12 & 16 \\
$\%$ & $57,50 \%$ & $60,0 \%$ & $80,0 \%$ \\
\hline
\end{tabular}

Gambar 1. Grafik perkembangan kemampuan guru dalam mengelolah dan mengendalikan direct instruction tiap siklus.

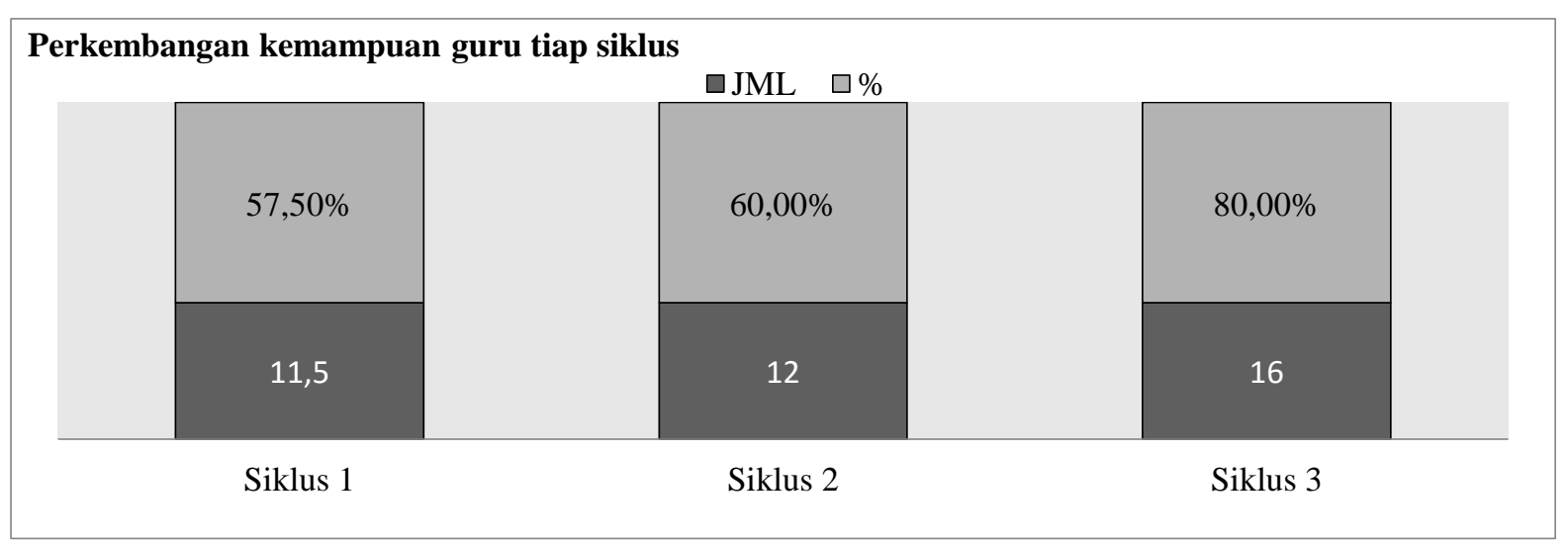

\section{Hasil penelitian aktivitas peserta didik}

Hasil penelitian aktivitas peserta didik dalam melaksanakan tindakan pembelajaran model direct instruktion dengan pendekatan scientific tiap siklus. Siklus satu mencapai jumlah skor 362,5 dengan $58,47 \%$. Siklus dua materi IPS dianalisis secara deskriptif mengoprasikan program SPSS for windows, untuk mengetahui tercapai tidaknya kualitas peningkatan hasil belajar materi IPS tiap siklus. Jika siklus bersangkutan belum mencapai standar, dilanjutkan pemberian tindakan pada siklus selanjutnya, tetapi jika siklus sudah mencapai standar kualitas peningkatan tiap siklus, menurut indikator hasil yang telah ditentukan, dihentikan pemberian tindakan pada siklus selanjutnya.

\section{HASIL DAN PEMBAHASAN}

\section{Hasil penelitian kemampuan guru}

Hasil penelitian kemampuan guru dalam mengelolah dan mengendalikan tindakan pembelajaran model direct instruktion dengan pendekatan scientific tiap siklus. Siklus satu mencapai 57,50\% dari jumlah skor 11,5. Siklus dua mencapai 60,00\% dari jumlah skor 12 . Siklus tiga mencapai $80,00 \%$ dari dari jumlah skor 16. Diuraikan menurut tabel 2 dan gambar 1 berikut: 
Tabel 3. Hasil penelitian aktivitas peserta didik tiap siklus

\begin{tabular}{cccc}
\hline \multirow{2}{*}{ Uraian } & \multicolumn{4}{c}{ Perkembangan aktivitas peserta didik tiap siklus } \\
& Siklus 1 & Siklus 2 & \\
\hline JML & 362,5 & 381 & 443 \\
$\%$ & $58,47 \%$ & $61,45 \%$ & $71,45 \%$ \\
\hline
\end{tabular}

Gambar 2. Grafik perkembangan aktivitas peserta didik tiap siklus.

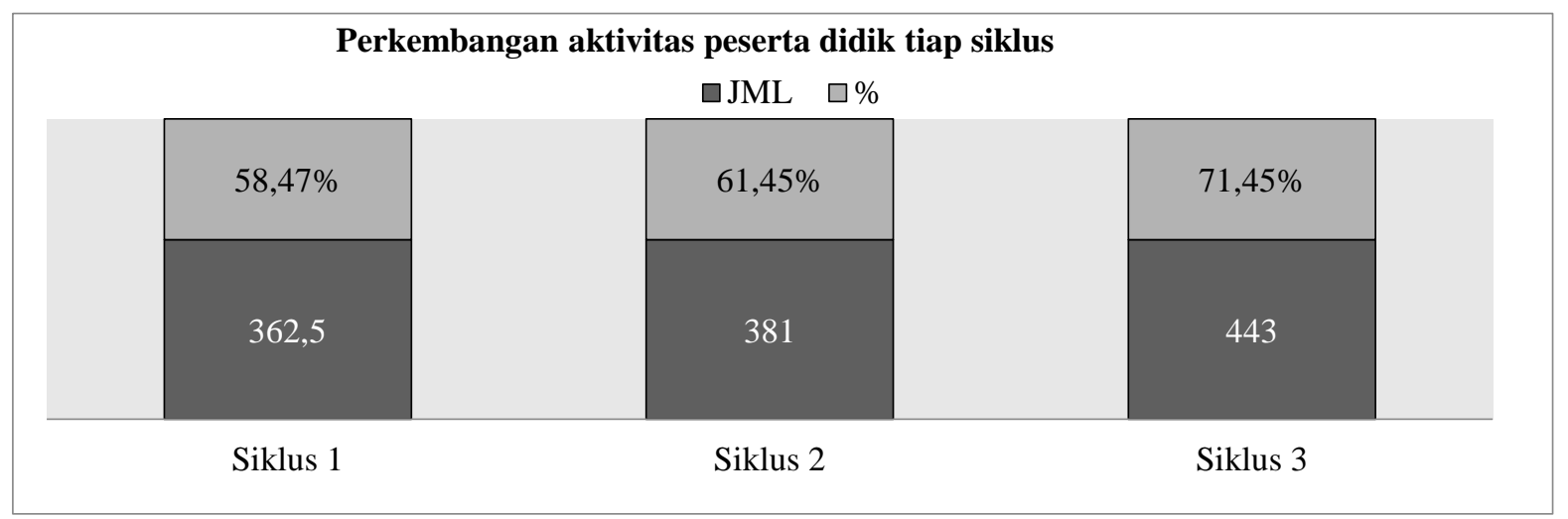

\section{Hasil penelitian hasil belajar materi IPS}

Hasil penelitian hasil belajar materi IPS tiap siklus. Siklus satu mencapai skor rerata
70,35. Siklus dua mencapai skor rerata 71,87. Siklus tiga mencapai rerata 84,13 . Diuraikan menurut tabel 4 dan gambar 3 berikut:

Tabel 4. Hasil penelitian hasil belajar materi IPS tiap siklus

\begin{tabular}{cccc}
\hline \multirow{2}{*}{ Uraian } & \multicolumn{3}{c}{ Perkembangan belajar materi IPS tiap siklus } \\
& Siklus 1 & Siklus 2 & Siklus 3 \\
\hline Rerata & 70,35 & 71,87 & 84,13 \\
Standar Deviasi & 11,580 & 11,698 & 6,158 \\
Varians & 134,103 & 136,849 & 37,916 \\
\hline
\end{tabular}

Gambar 3. Grafik perkembangan hasil belajar materi peajaran IPS tiap siklus.

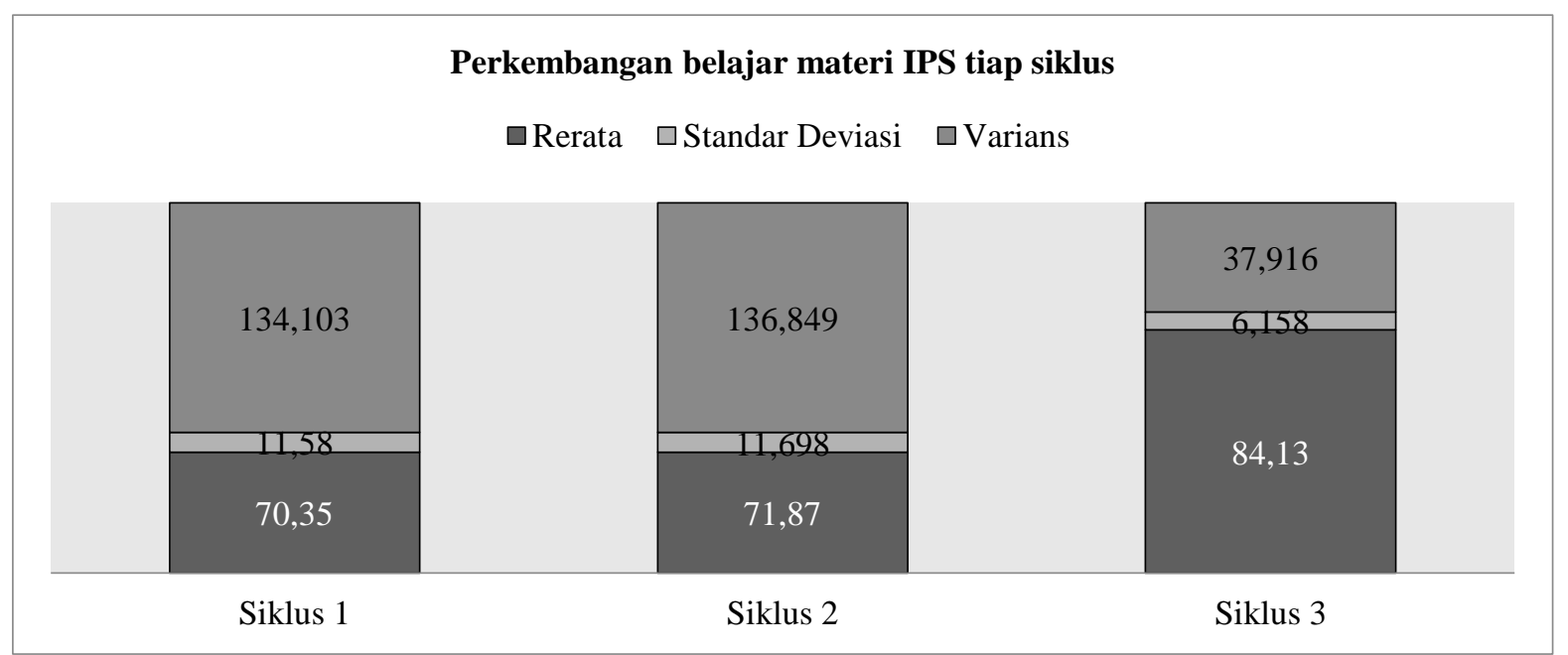

Sedangkan hasil penelitian ketuntasan belajar minimal hasil belajar materi IPS tiap siklus. Siklus satu mencapai peserta didik yang tuntas belajar $51,48 \%$ dan yang tidak tuntas adalah $45,16 \%$. Siklus dua mencapai peserta didik yang tuntas $67,74 \%$, yang tidak tuntas $32,25 \%$. Siklus tiga mencapai peserta didik yang 
tuntas $90,32 \%$ dan yang tidak tuntas 9,68\%. Diuraikan menurut tabel 5 dan gambar 4 berikut:

Tabel 5. Hasil penelitian ketuntasan belajar minimal materi IPS tiap siklus

\begin{tabular}{cccc}
\hline \multirow{2}{*}{ Kategori } & \multicolumn{3}{c}{ Perkembangan ketuntasan belajar minimal materi } \\
& \multicolumn{3}{c}{ IPS tiap siklus } \\
& Siklus 1 & Siklus 2 & Siklus 3 \\
\hline Tuntas & $51,48 \%$ & $67,74 \%$ & $90,32 \%$ \\
Tidak Tuntas & $45,16 \%$ & $32,26 \%$ & $9,68 \%$ \\
\hline
\end{tabular}

Gambar 4. Grafik perkembangan ketuntasan belajar minimal materi IPS tiap siklus.

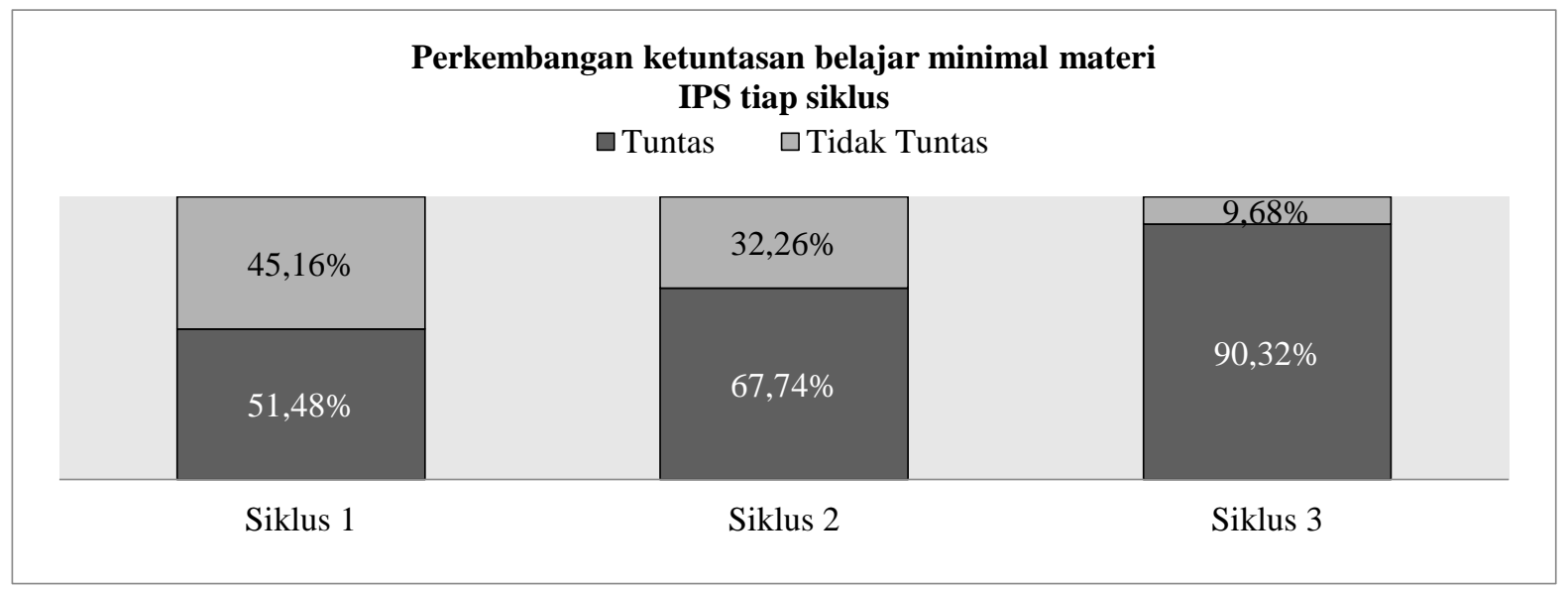

\section{Pembahasan}

Pelaksanaan tindakan pembelajaran model direct instruction dengan pendekatan scientific siswa kelas VII 4 SMPN 1 Tanete Rilau kabupaten Barru, menyebabkan peningkatan hasil belajar materi IPS. Ditunjukkan adanya perubahan-perubahan dari hasil pengamatan, maupun peningkatan skor rata-rata hasil belajar siswa selama pelaksanaan penelitian setiap siklus.

Penyebab lainnya ditunjukkan adanya perubahan kehadiran dan aktivitas siswa dan kemampuan guru dalam melaksanakan pembelajaran. Perubahan-perubahan tersebut merupakan data kualitatif yang diperoleh dari lembar observasi pada setiap pertemuan yang dicatat oleh guru dan observer selama penelitian berlangsung. Adapun perubahan-perubahan yang dimaksud sebagai berikut:

Indikator kehadiran siswa secara keseluruhan dalam melaksanakan tindakan dan tes telah menunjang secara positif penelitian ini karena tingkat kehadiran yang dicapai 100\% dari siklus satu sampai siklus tiga.

Indikator keaktifan peserta didik dalam melaksanakan tindakan model pembelajaran direct instruktion dengan pendekatan scientific, tidak mengalami perubahan secara positif dari siklus satu ke siklus dua, karena meningkat skor persentase selisih 2,98\% tetapi tidak meningkat kategori yaitu cukup tetap menjadi cukup dan kualitas kategori dan skor persentase pada siklus dua tidak mencapai standar kualitas lebih besar dari 62,5 atau minimal kategori baik, menurut indikator keberhasilan aktivitas peserta didik dalam penelitian ini. Baru siklus dua ke siklus tiga mengalami perubahan secara positif, karena meningkat skor persentase selisih $10 \%$, meningkat kategori cukup menjadi baik, serta kualitas kategori dan skor persentase pada siklus tiga telah mencapai standar kualitas lebih besar dari $62,5 \%$ atau minimal kategori baik, menurut indikator keberhasilan aktivitas peserta didik dalam penelitian ini.

Indikator hasil belajar materi pelajaran IPS secara keseluruhan tidak mengalami perubahan peningkatan rerata dan kategori dari siklus satu ke siklus dua, karena meningkat rerata selisih 1,52, tetapi tidak meningkat kategori tetap cukup dari siklus satu ke siklus dua serta kualitas rerata dan kategori tidak mencapai standar minimal 75 menurut indikator hasil belajar materi IPS siklus dua. Baru siklus dua ke siklus tiga mengalami perubahan secara positif, karena meningkat rerata selisih 12,26 , meningkat kategori kurang menjadi baik dan kualitas kategori dan skor rerata pada siklus tiga mencapai standar kualitas hasil belajar materi 
IPS menurut indikator keberhasilan hasil belajar penelitian ini.

Indikator ketuntasan belajar minimal hasil belajar materi IPS siklus satu, peserta didik yang tuntas belajar belum mencapai standar kualitas minimal $85 \%$. Siklus dua juga demikian, belum mencapai standar kualitas minimal $85 \%$. Baru pada siklus tiga telah mencapai standar minimal $85 \%$.

Indikator kemampuan guru dalam mengelolah dan mengendalikan tindakan model direct instruktion dengan pendekatan scientific, mengalami peningkatan skor persentase dan kategori dari siklus satu ke siklus dua selisih $2,2 \%$, tidak meningkat kategori tetap kategori cukup dan tidak mencapai standar kualitas skor persentase lebih besar 62,5. Baru siklus dua ke siklus tiga mengalami perubahan secara positif, karena meningkat skor persentase selisih 20\%, meningkat kategori cukup menjadi baik. Serta kualitas pesentase dan kategori

telah mencapai standar lebih besar $62,5 \%$ atau minimal kategori baik.

\section{SIMPULAN DAN SARAN Simpulan}

Hasil penelitian ini disimpulkan bahwa: (1) Model pembelajaran direct instruction meningkat rerata selisih 12,26, meningkat kategori kurang menjadi baik dari siklus dua ke siklus tiga. Kualitas kategori dan skor rerata pada siklus tiga 84,13 , telah mencapai standar kualitas minimal 75 hasil belajar materi IPS menurut indikator keberhasilan hasil belajar penelitian ini. (2) Persentase ketuntasan belajar materi IPS mencapai 90,32\% siklus tiga, telah mencapai standar kualitas tuntas belajar minimal 85\% menurut indikator penelitian ini. (3) Perubahan secara positif kemampuan meningkat skor persentase selisih $20 \%$, meningkat kategori cukup menjadi baik dari siklus dua ke siklus tiga. Serta kualitas pesentase $80,00 \%$ dan kategori baik siklus tiga, telah mencapai standar lebih besar $62,5 \%$ atau minimal kategori baik. (4) Perubahan aktivitas peserta didik meningkat skor persentase selisih $10 \%$, meningkat kategori cukup menjadi baik, serta kualitas kategori baik dan skor persentase $71,45 \%$ pada siklus tiga, telah mencapai standar kualitas lebih besar dari $62,5 \%$ atau minimal kategori baik, menurut indikator keberhasilan aktivitas peserta didik dalam penelitian ini.

\section{Saran}

Penulis menyarankan bahwa: (1) Pertahankan peningkatan hasil belajar materi IPS melalui model pembelajaran direct instruction dengan pendekatan scientific, siswa kelas $\mathrm{VII}_{4}$ SMPN 1 Tanete Rilau Kabupaten Barru. (2) Pertahankan persentase ketuntasan belajar materi IPS, siswa kelas $\mathrm{VII}_{4}$ SMPN 1 Tanete Rilau kabupaten Barru minimal 85\%. (3) Pertahankan perubahan secara positif kemampuan guru dalam mengelolah dan mengendalikan model pembelajaran direct instruction dengan pendekatan scientific. (4) Pertahankan perubahan secara positif aktivitas peserta didik melaksanakan model pembelajaran direct instruction dengan pendekatan scientific.

\section{DAFTAR RUJUKAN}

Ali, Muhammad. 2004. Guru Dalam Proses Belajar Mengajar. Bandung: Sinar Baru Algesindon.

Anonim, 1999. Bahan Pelatihan Dosen LPTK dan Guru Sekolah Menengah. Departemen Pendidikan Kebudayaan. Jakarta: Direktorat Jenderal Pendidikan Tinggi Proyek Pengembangan Guru Sekolah Menengah (Secondary School Teaher Development Project) IBRD Loan No. 3979-IND.

Anonim, 2008. Kamus Umum Bahasa Indonesia. Edisi ke IV. Departemen Pendidikan Nasional. Jakarta: PT Gramedia Pustaka Utama.

Anonim. 2010. Belajar dan Hasil Belajar, (online), http://techonly 13.wordpress. com/2010/07/03/belajar-dan-hasilbelajar/, diakses 3 Juli 2010.

Anonim. 2011. Pengertian hasil belajar, (online),http//www.sarjanaku.com/201 1/03/pengertian-definisi-hasilbelajar.html.

Anonim.2011.https://akhmadsudrajat.wordpress. com/2011/01/27/model-pembela jaran-langsung).

Anonim. 2016. Permendikbud No. 024 Lampiran 1 KI,KD Mata Pelakjaran Ilmu Pengetahuan Sosial. Jakarta: Menteri Pendidikan dan Kebudayaan.

Anonim. 2017a. Ilmu Pengetahuan Sosial. Buku siswa SMP/MTS kelas VII. Jakarta: Menteri Pendidikan dan Kebudayaan.

Anonim. 2017b. Ilmu Pengetahuan Sosial. Buku guru SMP/MTS kelas VII. Jakarta: Menteri Pendidikan dan Kebudayaan.

Anonim. 2017c. Panduan Penilaian oleh Pendidik dan Satuan Pendidikan untuk Sekolah Menengah Pertama. Kementerian pendidikan dan 
kebudayaan Direktorat pembinaan sekolah menengah pertama, cetakan ketiga 2017.

Dayan, Anto. 1972. Pengantar Metode Statistik Deskriptif. Lembaga Penelitian Pendidikan dan Penerangan Ekonomi.

Hadi, Sutrisno. 1981. Metodogi Research. Yayasan Penerbitan Fakultas Psikologi Universitas Gajah Mada. Yoyakarta.

Hamalik, Oemar. 1992. Psikologi Belajar dan Mengajar. Bandung: Sinar Baru.

Harjani. 2010. Upaya Meningkatkan Prestasi Belajar Siswa Dengan Penerapan Model Pembelajaran Direct Instruction Pada Mata Pelajaran Akuntansi Kelas X Akuntansi 1 SMK Negeri 1 Sukoharjo Tahun Ajaran 2009/2010. Skripsi. Surakarta. Fakultas Keguruan dan Ilmu Pendidikan. Universitas Sebelas Maret Surakarta.

Milles., Huberman. 1992. Analisis Data kualitatif. Terjemahan Rohendi Rohidi. Jakarta: Universitas Indonesia.

Mukhlis, Abdul. (Ed). 2000. Penelitian Tindakan Kelas. Makalah Panitian Pelatihan Penulisan Karya Ilmiah untuk Guru-guru se-Kabupaten Tuban.

Nur, Moh. 2001. Pemotivasian Siswa untuk Belajar. Surabaya. University Press. Universitas Negeri Surabaya.

Riyanto,Yatim, H,Dr, Prof, 2009. Paradiqma Baru Pembelajaran. Jakaeta. Kencana Prenadamedia group.

Sandra, lusiana. 2010. Teori Belajar Social. Tersedia pada: http://scribd.com/ doc/45186694/teori-belajar-sosial. Diakses pada tanggal 9 Oktober 2013 pukul 20.00 WITA.

Sardiman, A.M. 1996. Interaksi dan Motivasi Belajar Mengajar. Jakarta: Bina Aksara.

Santrock, John W. 2004. Psikologi Pendidikan Edisi Kedua . Terjemahan Tri Wibowo B.S. 2008. Jakarta: Kencana.

Sugiyono. 2016. Metode Penelitian Pendidikan. Bandung: Alfabeta.

Suprijono, Agus. 2009. Cooperative Learning: Teori dan Aplikasi PAIKEM. Yogyakarta: Pustaka Belajar.

Widoyoko, Putro, Eko, S. 2012. Teknik Penyusunan Instrumen Penelitian. Yokyakarta. Pustaka pelajar.

Winkel, W.S. 1996. Psikologi Pengajaran. Jakarta: PT. Gramedia Widiasarana Indonesia.
Yandianto. 1996. Kamus Umum Bahasa Indonesia. Bandung. M2s Bandung. 